\title{
RELEVANSI JADWAL WAKTU SALAT SEPANJANG MASA
}

\author{
Riza Afrian Mustaqim \\ Universitas Islam Negeri Ar-Raniry Banda Aceh \\ e-mail: riza.mustaqim@ar-raniry.ac.id
}

\begin{abstract}
Practically determining the timing of prayers is a primary need in Islam. The schedule of prayer times throughout the ages was an alternative reference in starting the beginning of prayer times. This is because it is deemed sufficient to provide a solution in starting and ending prayers. On the other hand, the existence of an all-time prayer schedule needs to be reviewed for its accuracy. The data of the sun, which always changes every year, is one of the factors for the difference in time in each year, so this will conflict with the prayer time schedule for all time which refers to the same data for all time. Not to mention the coordinates of the latitude and longitude of the place and the height of the place which is large and small will affect the calculation results. This research is a research library (library research) which aims to describe the relevance of prayer timelines throughout the time, as well as to provide alternatives to its validity. The results of this study indicate that there are several factors that cause the irrelevance of the use of prayer times throughout this time, including: the use of latitude and longitude of a place that refers to a point in an area, the use of the equation of time and the average solar declination. and there is no standardization of ihtiyath time.
\end{abstract}

Keywords: Relevance, Schedule, Prayer Times, All Time

\begin{abstract}
ABSTRAK
Penentuan waktu salat secara praktis merupakan kebutuhan primer dalam Islam. Jadwal waktu waktu salat sepanjang masa pernah menjadi alternatif acuan dalam mengawali awal waktu-waktu salat. Pasalnya hal tersebut dipandang cukup memberikan solusi dalam memulai dan mengakhiri salat. Disisi lain, keberadaan jadwal waktu salat sepanjang masa perlu dikaji kembali tingkat akurasinya. Data matahari yang selalu berbubah-ubah dalam setiap tahunnya menjadi salah satu faktor terjadinya perbedaan waktu dalam setiap tahunnya, sehingga hal ini akan bertentangan dengan jadwal waktu salat sepanjang masa yang mengacu kepada suatu data yang sama untuk sepanjang masa. Belum lagi koordinat lintang dan bujur tempat serta tinggi tempat yang besar kecil akan mempengaruhi hasil perhitungan. Penelitian ini merupakan penelitian kepustakaan (library research) yang bertujuan untuk mendeskripsikan relevansi dari jadwal waktu salat sepanjang masa, serta memberikan alternatif keberlakuannya. Hasil penelitian ini menunjukkan bahwa terdapat beberapa faktor yang menyebabkan tidak relevannya penggunaan jadwal waktu salat sepanjang masa ini, diantaranya: penggunaan lintang dan bujur tempat yang mengacu kepada satu titik dalam suatu daerah, penggunaan equation of time (perata waktu) dan deklinasi matahari rata-rata dan belum adanya standarisasi waktu ihtiyath.
\end{abstract}


Kata Kunci: Relevansi, Jadwal, Waktu Salat, Sepanjang Masa

\section{PENDAHULUAN}

Para ahli hisab sepakat awal waktu salat ditentukan oleh sudut waktu matahari $\left(t_{0}\right)$. Awal waktu zuhur, saat matahari berkulminasi atas persis pada meridian langit, sudut waktunya $\left(t_{o}=0^{\circ}\right)$. Waktu Asar, Maghrib, dan Isya, ketika matahari bergeser ke Barat pada sore hari sampai saat kulminasi bawah (tengah malam) sudut waktunya positif $\left(t_{o}=+\right)$. Dan waktu Subuh, termasuk Syuruk dan Dhuha, ketika matahari berbalik di pagi hari hingga titik kulminasi atas, sudut waktunya negatif ( $\mathrm{tm}=-$ ). (A. Kadir, 2014)

Pada mulanya penentuan awal waktu salat hanya menggunakan metode penglihatan langsung (rukyat) seperti melihat bayang-bayang Matahari dengan bantuan tongkat istiwa'1(Azhari, n.d.) untuk mengetahui awal waktu salat Zuhur dan Asar, melihat fenomena alam seperti pada saat terbenamnya Matahari sebagai pertanda dimulainya awal waktu Magrib, pudarnya mega merah (syafaq al-ahmar) sebagai pertanda masuknya waktu Isya, dan terbitnya fajar shadiq sebagai pertanda masuknya waktu Subuh, sebagaimana yang telah dijelaskan pada hadis-hadis Nabi tentang salat (Jayusman, 2013). Kemudian muncul metode lain dalam menentukan awal waktu salat yaitu dengan cara menghitung (menghisab), yang berarti menentukan awal waktu salat dengan cara menghitung posisi Matahari sesuai yang dijelaskan syar'i berdasarkan peredarannya.

Seiring berkembangnya zaman dengan ditandainya munculnya aneka teknologi modern dengan berbagai kelebihan dan kekurangan yang dimiliki, dan dengan melihat perkembangan hidup manusia yang semakin bergantung pada hal-hal yang sifatnya praktis dan instan, sehingga dapat membantu manusia khususnya umat Islam dengan begitu mudahnya untuk menentukan awal waktu salat tanpa harus melihat fenomena alam yang terjadi, dengan tanpa mengesampingkan keakuratan dari ketentuan syar'i, disediakan atau dihadirkanlah beberapa sarana pembantu dalam penentuan awal waktu salat tersebut. Yaitu dengan munculnya aneka software-software ${ }^{2}$ baik itu menggunakan aplikasi komputer offline ataupun online, ataupun juga aneka jadwal waktu salat abadi yang telah dihitung oleh beberapa ahli falak dan juga telah terpasang di beberapa masjid. Namun, masih terdapat beberapa kalangan yang meragukan kesahihan dari jadwal waktu salat abadi tersebut. Baik itu karena kurangnya

${ }^{1}$ Istiwa' (tongkat istiwa') merupakan tongkat yang biasa ditancapkan tegak lurus pada bidang datar di tempat terbuka (sinar Matahari tidak terhalang). Kegunaannya untuk menentukan arah secara tepat dengan menghubungkan dua titik (jarak kedua titik ke tongkat harus sama) ujung bayangan tongkat saat Matahari disebelah timur dengan ujung bayangan setelah Matahari bergerak ke barat. Kegunaan lainnya adalah untuk mengetahui secara persis waktu Zuhur, tinggi Matahari, dan -setelah menghitung arah barat- menentukan arah kiblat. Adapun yang disebut dengan istiwa' (waktu istiwa') adalah waktu yang didasarkan pada perjalanan Matahari hakiki. Menurut waktu hakiki, Matahari berkulminasi pada pukul 12.00 dan berlaku sama untuk setiap hari dan untuk dijadikan waktu rata-rata, dikoreksi dengan perata waktu atau equation of time.

${ }^{2}$ Software-software tersebut salah satunya adalah software Islamic finder, software awal waktu salat oleh Ahmad Izzuddin, software Shollu dan juga software mawaqit oleh Ing Khafidz, dsb. Dengan beberapa software tersebut kita bisa menentukan awal waktu salat secara praktis, yaitu cukup dengan menyesuaikan daerah yang akan dihitung awal waktu salatnya. 
pengetahuan mereka, ataupun memang berdasarkan pemahaman yang berbeda atas suatu teori atau metode penghitungan.

Jadwal waktu salat abadi disebut juga dengan jadwal waktu salat sepanjang masa ataupun jadwal salat untuk selama-lamanya. Penamaan itu karena jadwal waktu salat tersebut dapat digunakan dalam penentuan awal waktu salat untuk selama-lamanya, abadi atau sepanjang masa. Hal ini disebabkan karena awal dan akhir waktu salat ditentukan oleh posisi matahari, tidak tergantung pada fenomena alam. (A. Kadir, 2014) Pada jadwal waktu salat tersebut terdapat penentuan awal waktu salat selama satu tahun penuh dari bulan Januari sampai bulan Desember.

Fakta di lapangan bahwa terdapat banyak jadwal waktu salat yang dipergunakan oleh masyarakat. Di mana antara jadwal yang satu dengan lainnya tersebut memiliki waktu yang berbeda. Jadwal waktu salat tersebut ada yang disebutkan sumber penyusunannya namun banyak pula yang tidak disebutkan. Satu jadwal dengan jadwal lainnya ada yang berbeda 3 atau 5 menit, bahkan bisa lebih dari itu. Hal ini akan berdampak kepada akurasi dari hasil perhitungan jadwal waktu salat tersebut. Data matahari yang digunakan sebagai acuan penentuan awal waktu salat juga mengalami perubahan dalam setiap tahunnya, sehingga penggunaan jadwal waktu salat sepanjang masa perlu ditinjau kembali relevansinya.

\section{METODE PENELITIAN}

Penelitian ini merupakan penelitian kepustakaan (library research) yang bertujuan untuk mendeskripsikan relevansi dari jadwal waktu salat sepanjang masa, serta memberikan alternatif keberlakuannya. Dengan menggunakan analisis deskriptif penelitian ini akan mencoba memberikan kategorisasi dan kualifikasi faktor-faktor yang menyebabkan akurat atau tidaknya penggunaan jadwal waktu salat sepanjang masa di era modern ini. Jenis data yang digunakan dalam penelitian ini adalah data sekunder yang bersumber dari penelitian-penelitian berkaitan sebelumnya, serta bukubuku rujukan yang relevan. Data tersebut ditelaah kembali untuk menemukan relevansinya dengan situasi dan keadaan saat ini.

\section{PEMBAHASAN}

A. Jadwal Imsakiyah/Jadwal Waktu Salat

Waktu merupakan penyebab zhahir diwajibkannya salat, sementara penyebab hakikinya adalah perintah atau ketetapan dari Allah swt. Penetapan kewajiban (al-Ijab) disandarkan kepada Allah swt., sedangkan kewajibannya (al-Wujub) disandarkan kepada perbuatan hamba, yaitu salat (Hawwas, n.d.).

Jadwal waktu salat lebih masyhur dengan sebutan jadwal imsakiyah, namun jadwal imasakiyah lebih sering beredar dikalangan masyarakat pada saat bulan Ramadan. Jadwal imsakiyah merupakan jadwal yang digunakan memulai waktu puasa (imsak) dan mengakhiri puasa (ifthar), di samping di dalamnya terdapat jadwal salat wajib lima waktu(maghriba, isyak, subuh, zuhur dan asar) yang terkadang ditambah jadwal awal waktu dhuha dan terbit matahari. Sehingga dalam jadwal imsakiyah biasanya terdapat jadwal waktu imsak yang biasanya dengan mengurangi 8 menit atau 10 menit, 12 
menit atau 15 sebelum awalwaktu salat, sesuai ijtihad dalam memperkirakanwaktu nabi Muhammad saw., dalam membaca 50 ayat alQur'an ${ }^{3}$ Adanya waktu imsak sebelum waktu shubuh hanya merupakan tradisi masyarakat muslim Asia tenggara dalam rangka ihtiyath malam memulai puasa.

Keberadaan jadwal imsakiyah menjadi sebuah kebutuhan bagi masyarakat muslim. Mengingat keabsahan mengawali dan mengakhiri puasa wajib rmadan sangat tergantung kebenaran jadwal imsakiyah yang dipakai. Jadwal imsakiyah harus merupakanhasil rumusan dari pakar yang dapat dipertanggungjawabkan. Sehingga jika ada jadwal imsakiyah yang tidak menyebutkan sumber yang jelas yang dapat dipertanggungjawabkan, maka sangat dikhawatirkan dapat membatalkan pelaksanaan ibadah kita, karena data waktu mengawali ibadah salat tersebut tidak atau kurang tepat.

Merujuk kepada standarisasi hisab rukyat Kementerian Agama RI, maka hal-hal yang perlu distandarkan dalam menyusun jadwal imsakiyah adalah:

1. Algoritma atau rumus hisab awal salat dengan data yang diperlukan dalam menghitung ketinggian matahari.

2. Data titik koordinat (lintang dan bujur) yang dipakai. Selama ini masih banyak yang menggunakan data dari Atlas Der Gehele Aarde oleh PR Bos-JF Nier Meyer JB, Wolters Groningen, Jakarta, 1951. Padahal kita tidak tahu persis keakurasian data tersebut. Maka perlu disepakati untuk mempergunakan data lintang dan bujur yang terbaru dengan menggunakan markaz data di titik tengah kota atau kabupaten terkait. 4

3. Perlu dibangun kesepakatan pemberlakuan jadwal salat dalam wilayatul hukmi kabupaten atau kota. Tidak perlu membuat jadwal salat dalam tiap kecamatan apalagi tiap desa.

4. Waktu ikhtiyah yang disepakati. Waktu ikhiyath dikandung maksud sebagai langkah pengamanan dengan cara menambah atau mengurangi waktu agar jadwal waktu salat tidak mendahuluai awal waktu salat atau melampaui akhir waktu salat. Langkah yang ditempuh, pertama dengan dengan pembulatan angka dalam satuan detik dibulatkan menjadi satu menit. Kementerian agama RI sejak 1979, menggunakan ikhtiyah 2 menit sebagai mana Saaddudin Jambek, yang sudah dianggap cukup memberikan pengamanan yang mempunyai jangkauan sampai $55 \mathrm{~km}$ ke arah barat atau timur. (Departemen Agama Republik Indonesia, 1985)

\footnotetext{
${ }^{3}$ Hadis dari Anas bin Malik ra., dari Zaid bin Tsabit ra., ia berkata: Kami makan sahur bersama nabi Muhammadad saw., kemudian beliau berdiri untuk salat sya (Anas bin Malik) bertanya, berapa lama waktu antara azan dan sahur? Dia menjawab, sekitar bacaann 50 ayat. (HR. Bukhari dan Muslim)

${ }^{4}$ Lembaga yang berkompeten mengeluarkan data titik koordinatadalah Badan Informasi Geospasial (BIG) yang dulu bernama Bakosurtanal.
} 
5. Penulisan data tanggal satu berdasarkan kriteria hisab imkanurrukyah pemerintah, dalam hal ini Kementerian Agama RI (Izzuddin, 2017).

\section{B. Penyusunan Jadwal Waktu Salat}

Ada beberapa metode perhitungan awal waktu salat cukup banyak beredar di masyarakat, mulai dari cara tradisional, klasikal, sampai dengan kontemporer. Cara tradisional cenderung menggunakan peralatan astronomi seperti tongkat istiwa' ataupun sundial. Sedangkan hisab klasik, biasanya menggunakan metode kitab-kitab falak karya ulama ahli falak seperti: metode Syawariq al-Anwar karya Kyai Noor Ahmad Jepara, Kitab Durus al-Falakiyah karya Syekh Ma'shum bin Ali, Kitab al-Khulashah alWafiyyah karya Kyai Zubair Umar Jailani dan lain-lain. Sedangkan metode hisab kontemporer waktu salat dalam bentuk software yang dijalankan di komputer seperti Mawaaqit 2001 karya Dr-Ing Khafid, Winhisab 2010 dari Kementerian Agama, Accurate Times karya Muhammad Odeh, dan Algoritma Jean Meeus.

Menurut Oman Fathurohman SW ada beberapa hal yang harus diperhatikan dalam penyusunan jadwal waktu slat, di antaranya:

1. Lokasi perhitungan; dalam menyusun jadwal waktu salat perlu memastikan koordinat lintang $(\phi)$, bujur $(\lambda)$, dan tinggi tempat. Untuk memperoleh data tersebut, dapat menggunakan Global Position System (GPS) atau google earth.

2. Sumber data; Ada beberapa data yang digunakan dalam penyusunan jadwal waktu salat, data tersebut berupa deklinasi $(\delta)$ matahari, semi diameter (s.d.) matahari, dan equation of time (e) atau perata waktu; data tersebut bias bersumber dari ephemeris hisab rukyah kementerian agama RI pada tiap tahunnya.

3. Pengolahan data; data yang berupa deklinasi $(\delta)$ matahari, semi diameter (s.d.) matahari, dan equation of time (e) atau perata waktu diambil pada saat real time. Langkah pengolahan data dimulai dari melakukan prediksi waktu salat berdasarkan lokasi masing-masing. Data diolah dengan melakukan interpolasi dan diambil sesuai dengan prediksi waktu tersebut. Jika hasil perhitungan tidak sesuai (berbeda) dengan prediksi tersebut maka pengolahan dan pengambilan data diulang dengan berdasarkan pada hasil perhitungan terakhir. Jika masih belum sesuai, maka pengolahan dan pengambilan data siulang lagi, begitu seterusnya.

4. Tanggal awal bulan; tanggal awal bulan yang sedang dihitung didasarkan kepada kriteria wujudul hilal.

5. Metode perhitungan dan alat hitung; perhitungan dapat dilakukan secara otomatis menggunakan program kalkulator atau excel dan alat hitung kalkulator manual. 
6. Kedudukan Matahari pada awal waktu salat; sebelum perhtungan waktu-waktu salat dilakukan, terlebih dahulu ditetapkan kedudukan matahari pada awal-awal waktu salat tersebut. Sebagaimana berikut:

a. Awal waktu Zuhur

Waktu salat zuhur mulai masuk ketika seluruh piringan matahari sudah berada di bagian barat; dengan kata lain, ketika tepi piringan matahari sebelah timur persis melewati lingkaran meridian langit setempat. Kedudukan matahari seperti ini adalah ketika matahari berkulminasi atas ditambah lama waktu matahari bergerak melewati lingkarang meridian sebesar semi diameternya. Waktu kulminasi matahari menurut waktu matahari menengah (atau disebut juga ephemeris transit (e.t) atau meridian pass) adalah jam 12 dikurangi equation of time $(12 \mathrm{j}-\mathrm{e})$. Sedangkan lama waktu matahari bergerak sebesar semi diameternya adalah semi diameter (s.d.) matahari dibagi 15 (s.d./15). Dengan demikian awal waktu salat Zuhur ketika matahari memenuhi syarat: $(12 \mathrm{j}-\mathrm{e})+($ s.d./15). Hal ini didasarkan pada hadis 'Abdullah bin 'Amr r.a bahwa Nabi telah bersabda:

"Waktu salat Zuhur adalah ketika Matahari tergelincir sampai bayangan seseorang sama dengan panjangnya, selama belum datang waktu Asar"

b. Awal waktu Asar

Waktu asar mulai masuk ketika bayangan-bayanagn matahari sama panjang dengan bendanya ditambah panjang bayanganbayangan matahari pada saat matahari berkulminasi. Panjang bayangan-bayangan matahari pada saat matahari berkulminasi ditentukan oleh jarak antara Zenith tempat perhitungan dengan deklinasi matahari saat itu. Dengan kata lain, tergantung pada nilai $Z_{\mathrm{m}} . \quad Z_{\mathrm{m}}$ adalah jarak dari titik zenith ke mataharisaat matahari berkulminasi. $z_{m}$ diperoleh dengan formula: $z_{m}=\phi-\lambda$. Kedudukan matahari awal waktu salat Asar ditentukan menurut ketinggiannya (h) dengan formula: $\mathrm{h}=\operatorname{cotan}^{-1}\left(\tan z_{m}+1\right)$.

Hal itu didasarkan pada hadis 'Abdullah bin 'Amr r.a (AnNaisabury, n.d.). Juga berdasarkan hadis Jabir r.a: "Tentang imamah Jibril untuk Nabi saw dia berkata: 'Berdiri dan kerjakanlah salat 'Asar'." Beliau pun mengerjakan salar Asar ketika bayangan segala sesuatu sama dengan panjangnya. Kemudian malaikat itu datang pada hari kedua seraya berkata: 'Berdiri dan kerjakanlah salat 'Asar'. Beliau pun mengerjakan salat 'Asar' ketika bayangan segala sesuatu sama dengan dua kali lipatnya (Asy-Syaukani, n.d.).

\section{c. Awal waktu Maghrib}

Waktu salat maghrib mulai masuk ketika matahari mulai terbenam. Matahari dikatakan terbenam apabila tepi pinggiran atas matahari di ufuk barat menurut penglihatan pengamat persisi berada pada lingkaran horizon mar'i. Kedudukan matahari awal waktu salat 
maghrib ditentukan menurut ketinggian (h) dengan formula; $h=-($ s.d. + ref + Dip), dimana s.d. adalah semi diameter matahari, Ref adalah refraksi matahari, dan Dip $=1,76 \sqrt{ } \mathrm{m}$. $\mathrm{m}$ adalah tinggi tempat dari permukaan laut menurut satuan ukur meter.

Seperti yang diriwayatkan oleh Imam Muslim dalam kitab Subulus Salam (Bukhari, 1992) "Yang lebih afdal adalah salat di awal waktu". Hal itu didasarkan pada hadis Jabir r.a tentang imamah Jibril bagi Nabi saw: "Jibril pernah mendatangi beliau pada waktu Magrib seraya berkata: "Berdiri dan kerjakanlah salat Magrib”. Beliau pun mengerjakan salat Magrib ketika Matahari terbenam. Kemudian Jibril mendatangi beliau lagi pada hari kedua pada waktu Magrib masih berlalu dari beliau (Asy-Syaukani, n.d.).

\section{d. Awal waktu Isya}

Waktu salat isya mulai masuk ketika mega merah di ufuk barat menghilang. Keadaan ini didefenisikan dengan ketinggian matahari (h) $-18^{\circ}\left(18^{\circ}\right.$ di bawah horizon). Untuk akhir daripada batasan mengerjakannya ada 3 pendapat yang masing-masing mempunyai landasan yang kuat, diantaranya pada pertengahan malam, pertiga malam, dan pendapat yang ketiga waktu terbit fajar shadiq. ${ }^{5}$ (Hambali, 2011).

\section{e. Awal waktu Subuh}

Waktu salat subuh mulai masuk ketika terbit fajar di ufuk timur. Keadaan ini didefenisikan dengan ketinggian matahari (h) $-20^{\circ}$ ( $-20^{\circ}$ di bawah horizon). Hal itu didasarkan pada hadis 'Abdullah bin Amr r.a (Bukhari, 1992).

Di antara dalil yang memperkuat pentingnya menyegerakan salat Subuh dan mengerjakan pada waktu malam masih pekat adalah hadis Jabir r.a tentang imamah Jibril untuk salat Nabi saw yang di dalamnya disebutkan: "kemudian Jibril mendatangi beliau pada waktu salat Subuh seraya berkata: 'kerjakanlah salat Subuh.' Beliau pun mengerjakan salat Subuh ketika fajar telah terbit atau ketika fajar telah bersinar terang. Kemudian Jibril mendatangi beliau lagi keesokan harinya ketika pagi sudah terang lalu dia berkata kepada beliau: 'Berdiri dan kerjakan salat Subuh.' Beliau pun mengerjakan salat Subuh kemudian berkata: 'antara kedua salat itu terdapat waktu (Subuh)." (Asy-Syaukani, n.d.) Waktu subuh berakhir ketika awal bulatan matahari telah terbit (Hazm, 1980).

\section{f. Waktu Syuruq (terbit matahari)}

Waktu syuruq (matahari terbit) didefenisikan apabila tepi pinggiran atas matahari di ufuk timur menurut penglihatan pengamat persis berada pada lingkaran horizon mar'i. Kedudukan matahari waktu syuruq ditentukan menurut ketinggian (h) dengan formula: $h=$

\footnotetext{
${ }^{5}$ Fajar shadiq adalah cahaya putih agak terang yang menyebar di ufuk timur yang muncul beberapa saat sebelum matahari terbit. Cahaya ini muncul pada saat matahari berada sekitar $18^{\circ}$ di bawah ufuk.
} 
-(s.d. + ref + Dip), dimana s.d. adalah semi diameter matahari, Ref adalah refraksi matahari, dan $\operatorname{Dip}=1,76 \sqrt{ } \mathrm{m} . \mathrm{m}$ adalah tinggi tempat dari permukaan laut menurut satuan ukur meter.

g. Awal waktu Dhuha

Kedudukan matahari waktu dhuha ditentukan menurut ketinggian $(\mathrm{h})$ yaitu $\mathrm{h}=04^{\circ} 42^{\prime}$.

h. Waktu Imsak

Waktu imsak adalah awal waktu salat Subuh dikurangi 10 menit.(Fathurohman, 2017)

Dalam perhitungan awal waktu salat, dikenal adanya waktu Ihtiyath. Ihtiyat adalah angka pengaman yang ditambahkan pada hasil hisab waktu salat. Dengan maksud agar seluruh penduduk suatu kota, baik yang tinggal di ujung Timur dan Barat kota, dalam mengerjakan salat sudah benarbenar masuk waktu. Secara teoritik selisih $1^{\circ}$ bujur sama dengan $111 \mathrm{~km}$ dan perbedaannya 4 menit dalam ukuran waktu. penggunaan ihtiath 1 menit sama dengan 111:4 = jarak 27,75 km (dalam arah Barat - Timur). Namun pemakalah menyebut bahwa ihtiyath sebenarnya tidak hanya berkaitan dengan bujur saja, namun juga dengan ketinggian tempat. Bagi ahli Falak yang dalam perhitungan awal waktu salat yang memperhitungkan kerendahan ufuk hanya melakukan koreksian ketinggian tempat, semidiameter, dan refraksi. Suatu kota atau daerah adakalanya tidak rata, terdapat bagian yang tinggi dan ada bagian yang rendah. Daerah yang tinggi akan mendapati matahari terbenam lebih belakangan dari daerah yang rendah (biasanya dekat pantai). Jadi ihtiyath juga untuk mengantisipasi kondisi tersebut.

Dalam pemberian waktu ihtiyath, terdapat perbedaan di kalangan ahli Falak sebagai berikut:

a. Kalangan pesantren tertentu tidak mencantumkan waktu ihtiyath dalam jadwal salat yang dibuat. Azan sebagai pertanda masuknya awal waktu salat dilaksanakan sesuai dengan waktu yang sebenarnya. Jadwal yang dibuatnya ini bersifat internal; hanya diberlakukan di pondok pesantren yang bersangkutan.

b. Noor Ahmad SS menggunakan Ihtiyath 3 menit untuk setiap perhitungan awal waktu salat. Kecuali untuk awal waktu Zuhur, menggunakan ihtiyath 4 menit.

c. Ibnoe Zahid Abdo el-Moeid dalam Imasakiah $1430 \mathrm{H}$ lalu menggunakan Ihtiyath 2 menit untuk setiap perhitungan awal waktu salat. Kecuali untuk awal waktu Zuhur, ia menggunakan ihtiyath 4 menit.

d. Muhyidin Khazin menyatakan bahwa Ihtiyath dalam penentuan awal waktu salat sebenar 1 sampai 2 menit.

e. Zul Efendi; ahli Falak murid Arius Syaikhi, menggunakan ihtiyath satu atau dua menit dalam jadwal salat yang ia buat dan banyak dipakai di berbagai kota di Sumatera Barat. Besaran ihtiyath yang digunakan 
tergantung besar kecilnya kota yang dihitung jadwal salatnya tersebut (Jayusman, 2013).

\section{Tata Cara Penggunaan Pedoman Waktu Shalat Sepanjang Masa}

Guna terwujudnya Jadwal salat yang dapat dijadikan acuan perlu jadwal yang akurat. Sebuah jadwal salat yang akurat tidaklah rumit. Karena jadwal salat secara umum tidaklah membutuhkan tingkat ketelitian atau akurasi yang tinggi. Dalam perhitungan awal waktu salat tidak perlu dilakukan koreksian yang banyak sehingga memiliki akurasi yang tinggi. Hal ini karena beberapa hal:

a. Sebuah jadwal salat hanya mencantumkan waktu dalam ukuran jam dan menit. Tidak mencantumkan ukuran detiknya. Karena jika dalam perhitungan jadwal salat digunakan data-data yang riil dan dilakukan koreksi-koreksi posisi Matahari utuk perhitungan dengan akurasi tinggi, perubahan jadwal yang dihasilkan hanya pada hitungan detik. Perubahan ini tidak signifikan, lagi pula yang dibutuhkan dalam perhitungan awal waktu salat hanya sampai hitungan menit saja, tidak sampai pada hitungan detiknya.

b. Data deklinasi Matahari dan equation of time yang biasa digunakan dalam perhitungan awal waktu salat oleh para ahli Falak biasanya adalah data deklinasi Matahari pada waktu perhitungan awal waktu Zuhur. Jadi tidak menggunakan data-data riil untuk perhitungan masing-masing waktu salat. Ini berdasarkan argumentasi karena data deklinasi Matahari dalam satu hari itu tidak banyak perubahannya.

c. Dalam perhitungan jadwal waktu salat sepanjang masa, data deklinasi Matahari yang digunakan adalah data deklinasi Matahari rata-rata. Secara sederhana deklinasi Matahari itu berubah setiap empat tahun. Jadi data ratarata dalam empat tahunan itulah yang digunakan dalam perhitungan ini. Data ini relative hamper sama walaupun tidak eksak sama dengan data deklinasi riil pada saat dilakukan perhitungan, tapi tidak signifikan perubahannya dari tahun ke tahun walaupun dalam jangka waktu puluhan, ratusan, bahkan ribuan tahun (Jayusman, 2013).

Langkah-langkah yang perlu dilakukan dalam penggunaan Pedoman Waktu Salat Sepanjang Masa adalah sebagai berikut:

1. Mengetahui tanggal (Masehi) dan tempat yang akan dihitung.

Jadwal ini dibuat dengan perhitungan 3 hari sekali. Bagi tanggal yang tidak ada pada jadwal, digunakan jadwal yang terdekat letaknya. Misalkan bagi tanggal 2 dipakai jadwal tanggal 1, bagi tanggal 3 dipakai jadwal tanggal 4 dan demikian selanjutnya. Dengan kata lain, setiap waktu dalam jadwal pada umumnya digunakan bagi 3 tanggal berurutan. 
2. Mencari koordinat lintang dan bujur tempat serta koreksinya pada daftar yang telah disediakan pada buku tersebut (Bagian kedua halaman 100).

Karena pada pertama lintang-lintang tempatnya tercatat dengan bilangan yang bulat, sedangkan pada bagian kedua koordinatkoordinat lintangnya tercatat dalam pecahan persepuluhan, maka lintang pada bagian kedua kita jadikan bilangan yang bulat dengan cara: nilai koordinat lintang yang kurang dari $0,5^{\circ}$ kita hilangkan, dan sebaliknya jika nilai lintangnya $0,5^{\circ}$ atau lebih maka kita bulatkan menjadi $1^{\circ}$.

3. Cari waktunya, dan koreksi berdasarkan ketentuan dari tabel bagian kedua.

4. Jika berada di tempat dengan ketinggian lebih dari 31 meter dari ufuk, lakukan koreksi sesuai pada table koreksi ketinggian tempat. Untuk waktu Magrib ditambahkan sedangkan untuk waktu syuruq dikurangkan.

5. Setelah itu tambahkan $2^{\mathrm{m}}$ sebagai ihtiyath (Departemen Agama Republik Indonesia, 1985).

\section{Relevansi Jadwal Waktu Salat Sepanjang Masa}

Perbedaan pengambilan sumber data perata waktu, deklinasi yang diambil dari tabel astronomi yang berisi suku-suku periodic pergerakan matahari diantaranya ada yang menggunakan Rubu' al-mujayab, table astronomi Ulugh Beigh, Ephemeris Hisab Rukyat Kementrian Agama, Almanak Nautika Dinas Hidro Oseanografi, The Astronomical Almanac, Tables Of Motion of The Earth karya New Comb, Astronomical Tables Of The Sun, Moon and Planets karya Jean Meeus akan berpengaruh pada hasil perhitungan yang diperoleh. Begitu juga tinggi matahari bisa membuat hasil perhitungan awal waktu salat berbeda walaupun hanya selisih beberapa menit.

Dalam penentuan jadwal salat, data astronomi terpenting adalah posisi matahari dalam koordinat horizon, terutama ketinggian atau jarak zenit. Fenomena yang dicari kaitannya dengan posisi matahari adalah fajar (morning twilight), terbit, melintasi meridian, terbenam, dan senja (evening twilight). Dalam hal ini astronomi berperan menafsirkan fenomena yang disebutkan dalam dalil agama (al-Qur'an dan hadis Nabi) menjadi posisi matahari. Sebenarnya penafsiran itu belum seragam, tetapi karena masyarakat telah sepakat menerima data astronomi sebagai acuan, kriterianya relatif mudah disatukan (Thomas, 2010).

Input data dalam perhitungan waktu salat turut andil dalam penentuan akurasi pada output. Dalam perhitungan waktu salat input yang dibutuhkan berupa data koordinat tempat (markaz), zona waktu, DIP6, deklinasi, equation of time, kriteria altitude matahari, serta ihtiyat. Khusus

\footnotetext{
${ }^{6}$ Ketinggian lokasi dari permukaan laut $(\mathrm{H})$ menentukan waktu kapan terbitdan terbenamnya matahari. Tempat yang berada tinggi di atas permukaan laut akan lebih awal menyaksikan matahari terbit serta lebih akhir melihat matahari terbenam, dibandingkan dengan tempat yang lebih rendah. Satuan $\mathrm{H}$ adalah meter.
} 
untuk equation oftime dan deklinasi, jika dalam metode yang biasa dilakukan oleh orang umum adalah cukup dengan melihat pada tabel ephemeris yang tersedia, misalnya dari Ephemeris Hisab Rukyat Kantor Kementerian Agama.

Penentuan tanggal-tanggal yang akan dicantumkan dalam jadwal ada bermacam-macam tergantung selera penyusunnya. Ada yang memuat 3 hari sekali, 4 hari sekali atau 5 hari sekali. Perbedaan ini tidak menjadi masalah sebab untuk tiap-tiap tanggal yang tidak dimuat dapat dilakukan interpolasi (penyisipan) sendiri oleh pemakai. Namun demikian pemuatan tanggal-tanggal yang tidak terlalu jauh, seperti 3 hari sekali lebih baik daripada 5 atau 6 hari sekali sebab perbedaan data antara satu baris dengan baris berikutnya hanya berkisar 1 atau 2 menit bahkan sering sama. Dengan demikian para pemakai tidak perlu melakukan interpolasi sendiri untuk tanggal-tanggal yang tidak dimuat (Fahmi, 2017).

Ada beberapa faktor yang mempengaruhi perbedaan waktu salat satu tempat dengan tempat yang lainnya, di antaranya:

Pertama, koordinat lintang dan bujur tempat. Tidak semua daerah kabupaten/kota berada dalam satu koordinat yang sama. Hal ini menyebabkan akan adanya perbedaan jadwal waktu salat suatu tempat dengan tempat yang lainnya meskipun berada dalam satu wilayah pemerintahan. Jadwal waktu salat sepanjang masa yang beredar secara umum dibuat per kabupaten/kota, beberapa jadwal memiliki koreksian untuk bujur dan lintang yang berbeda dalam wilayah tersebut. Namun ada juga yang menggunakan jadwal yang sama dalam suatu wilayah tanpa adanya pengoreksian lintang dan bujur (Rahmi, 2014).

Kedua, tinggi tempat. Secara umum tinggi tempat tidak memberikan banyak pengaruh dalam perhitungan waktu salat namun pada prinsipnya tetap memiliki perbedaan. Hal ini akan terjadi suatu perbedaan yang cukup signifikan bagi daerah kabupaten/kota yang secara geografis tinggi tempatnya tidak sama.

Ketiga, acuan data matahari yang digunakan. Jadwal waktu salat sepanjang masa menggunakan data rata-rata untuk equation of time (perata waktu) dan deklinasi matahari. Namun faktanya jika kita mengacu kepada ephemeris hisab rukyat yang dikeluarkan oleh Kementerian Agama RI setiap tahunnya kedua data tersebut selalu berubah-ubah. Bahkan jika kita telusuri lebih jauh, akan ada perbedaaan yang signifikan terhadap tanggal dan bulan yang digunakan dalam jadwal waktu salat sepanjang masa.

Keempat, standar waktu ihtiyath. Ada banyak hal yang memicu terjadinya perbedaan dalam waktu ihtiyath, namun yang ingin penulis tonjolkan di sini adalah perbedaan tersebut akan berdampak pada hasil perhitungan awal waktu salat. Sehingga standarisasi waktu ihtiyath pada setiap waktunya perlu dilakukan, guna meminimalisir perbedaan dalam mengawali salat dalam setiap waktunya. Tidak adanya konsep ihtiyath ini menimbulkan permasalahan dalam praktek perhitungannya (Putra, 2012).

Menurut penulis, idealnya pembuatan jadwal waktu salat harus diperbaharui dalam setiap tahunnya. Tanpa menggunakan data rata-rata matahari untuk kebutuhan jadwal waktu salat sepanjang masa. Hal tersebut guna mencapai suatu akurasi yang tepat dengan presisi kesalahan yang minimum. Selain itu, perbedaan lintang dan bujur tempat yang cukup 
signifikan perlu dilakukan dengan perhitungan yang berbeda, yaitu berdasarkan koordinatnya masing-masing, sebab pengurangan atau penambahan beberapa menit dari jadwal acuan akan sangat berdampak kepada kekeliruan, meskipun hanya selisih beberapa menit. Sehingga dalam hal ini, tinggi tempat pada suatu tempat juga berpotensi untuk memberikan hasil perhitungan yang berbeda.

Pada dasarnya, jadwal waktu salat sepanjang masa dibuat sebagai tanda praktis masuknya waktu salat. Kesulitan dalam mendistribusikan jadwal waktu salat pada setiap tahunnya keseluruh daerah-daerah (terutama di Indonesia) juga menjadi faktor penyusunan jadwal waktu salat ini. Namun di era modern ini, kesulitan-kesulitan tersebut bukanlah suatu hal yang berarti, sehingga jika yang dikedapnkan adalah akurasi jadwal waktu salat, maka jadwal tersebut akan lebih tepat jika dibuat pada setiap tahunnya, dengan data astronomi terbaru, dan menggunakan koordinat pada daerah masing-masing (misalnya perkecamatan).

\section{E. PENUTUP}

Sebagai kesimpulan dari penelitian ini, jadwal waktu salat sepanjang masa tidak relevan untuk digunakan. Ada beberapa faktor yang memepengaruhi hal tersebut, di antaranya: pertama, penggunaan lintang dan bujur tempat yang mengacu kepada satu titik dalam suatu daerah, dimana hal tersebut akan berdampak kepada perbedaan awal waktu salat dengan daerah yang lebih jauh dari titik koordinat acuan. Kedua, penggunaan equation of time (perata waktu) dan deklinasi matahari ratarata akan menghasilkan waktu yang berbeda pula. Ketiga, belum adanya standarisasi waktu ihtiyath dalam setiap waktu salat yang berdampak kepada perbedaan jadwal waktu salat sepanjang masa yang disusun. 


\section{DAFTAR PUSTAKA}

A. Kadir. (2014). Quantum Ta'lim Hisab-Rukyat; Cara Cepat Pintar Kalkulasi Arah Kiblat Syar'I, Waktu-waktu Salat Abadi, Plus Awal Bulan dan Gerhana. Fatawa Publishing.

An-Naisabury, I. M. bin al-H. al-Q. (n.d.). Shahīh Muslim, Kitab "alMasaajid Wa Mawaadli'u as-Salat." dar al-Kitab al-ilmiyah.

Asy-Syaukani, M. bin A. bin M. (n.d.). Nailul Authar. dar al-Kitab.

Azhari, S. (n.d.). Ensiklopedi Hisab Rukyat. Pustaka Pelajar.

Bukhari, M. I. I. (1992). Sahih al-Bukhari. Daar al-Kutub al-'Ilmiyyah.

Departemen Agama Republik Indonesia. (1985). Pedoman Penentuan Jadwal Shalat Sepanjang Masa. Depag RI.

Fahmi, M. R. (2017). "Studi Komparasi Jadwal Salat Sepanjang Masa H.Abdurrani Mahmud Dengan Hisab Kontemporer." Jurnal Bimas Islam, 10.

Fathurohman, O. (2017). "Kaidah Penyusunan Jadwal Imsakiyah Ramadan 1438 H”,. In Kumpulan Makalah "Lokakarya Imsakiyah Ramadan 1438 H / 2017 M.” LP2M UIN Walisongo.

Hambali, S. (2011). Imu Falak 1; Penentuan Awal Waktu Shalat \& Arah Kiblat Seluruh Dunia. Program Pascasarjana UIN Walisongo.

Hawwas, A. A. M. A. dan A. W. S. (n.d.). Fiqh Ibadah (Al-Wasiht Fiul Fiqhil Ibadah).

Hazm, I. (1980). al-Muhallah; al-Mujallad al-Tsani. Dar al-Fikr.

Izzuddin, A. (2017). , "Jadwal Imsakiyah yang berbasis Unity Of Science." In Kumpulan Makalah "Lokakarya Imsakiyah Ramadan 1438 H / 2017 M." LP2M UIN Walisongo.

Jayusman. (2013). “Jadwal Salat Abadi." Jurnal Khatulistiwa; Journal Of Islamic Studies, 3.

Putra, N. T. (2012). Problematika Waktu Ihtiyath Dalam Pembuatan Jadwal Shalat. Jurisdictie, Jurnal Hukum Dan Syariah, 3.

Rahmi, N. (2014). Penyatuan Zona Waktu Dan Pengaruhnya Terhadap Penetapan Awal Waktu Shalat”. JURIS, 13.

Thomas, D. (2010). Arah Kiblat Tidak Berubah. https:/ / tdjamaluddin.wordpress.com/2010/05/25/arah-kiblat-tidakberubah/ 